\title{
Trade Liberalization and Customs Revenue in Vietnam
}

\author{
Thi Anh Tuyet LE ${ }^{1}$
}

Received: June 03, 2020 Revised: June 28, 2020 Accepted: July 09, 2020

\begin{abstract}
The study assesses the impact of trade liberalization factors on changes in customs revenues in Vietnam. Research data was conducted between 2002 and 2017 on the official website of the Government's Web Portal and The World Bank. This paper uses the vector error correction model to estimate the short-term and long term relationship between data series. The results have proven that tariff reductions have a positive effect on short-term and long-term customs revenues in Vietnam. However, the implementation of other international commitments on trade liberalization has positive short-term and long-term negative impacts on customs revenues in Vietnam. The study's results also show that exchange rate has no effect on changes in customs revenues in the short term but it has a strong impact on increasing customs revenues in the long run. Based on these findings, the article also suggests a number of policies to ensure customs revenues in Vietnam in future. In order to ensure customs revenues, the government of Vietnam should: (1) having some policy to improve the efficiency of customs management in Vietnam; (2) Building appropriate VND exchange rate policy; (3) Establishing reasonable non - tariff barriers to prevent fraud and ovations cause losses in customs revenues.
\end{abstract}

Keywords: Trade Liberalization, Tariff Reduction, VECM Model, Import Duties, Customs Revenue

JEL Classification Code: C22, F14, F15, H72, O24

\section{Introduction}

Trade liberalization is the removal of barriers created by countries in order to facilitate the movement of goods from one country to another on the basis of fair competition. The above mentioned barriers may be tariffs, import and export license, regulations on goods quality standards, phytosanitary certificate, taxation methods, etc. The above fences are all subjects of the agreements that the World Trade Organization (WTO) is overseeing the implementation. According to the comparative advantage theory, the greatest benefit of trade liberalization is the promotion of more and more countries participating in the trade and exchange of goods, thereby promoting economic growth. For consumers, easier

${ }^{1}$ First Author and Corresponding Author. Professor, International Economic Faculty, Banking University Ho Chi Minh City, Vietnam [Postal Address: 56 Hoang Dieu 2 Street, Linh Chieu Ward, Thu Duc District, Ho Chi Minh City, 700000, Vietnam]

Email: tuyetlta@buh.edu.vn

(c) Copyright: The Author(s)

This is an Open Access article distributed under the terms of the Creative Commons Attribution Non-Commercial License (http://Creativecommons.org/licenses/by-nc/4.0/) which permits unrestricted noncommercial use, distribution, and reproduction in any medium, provided the original work is properly cited. circulation of goods gives them the opportunity to choose better goods at lower prices. Consumers here also include manufacturers that import materials to produce other goods. It is no coincidence that countries have erected barriers that affect the circulation of goods. The reason for this is to protect domestic production from competition of external goods. This is significant because domestic production decline will affect unemployment rate and social stability. Trade barriers also help increase the state budget's revenue through tariff collection, reduction of foreign currency spent on the purchase of foreign goods, protection of human and animal health from the risk of disease from poor quality goods, etc. In particular, the purpose of generating revenue for the state budget is really important for developing countries. Trade liberalization at different levels will weaken or diminish the said barriers and thus affect the initial purpose of establishing these barriers. Therefore, considering the relationship between trade liberalization and customs revenue is always one of the important issues that countries pay attention to when implementing international integration.

Vietnam became the 150th member of WTO on January 11,2007 , which is an important milestone in the process of trade liberalization. Like other countries, right after joining the WTO, Vietnam also developed its own Integration 
Strategy suitable to the characteristics of the national economy. From an economic perspective, WTO accession as well as the expansion of trade liberalization have contributed significantly to economic growth, contributed to poverty reduction, and promoted trade and investment in Vietnam. However, the challenges posed for Vietnam are no less. In particular, the reform of collection activities for import and export goods is considered as one of the key issues in the financial sector. Compliance with these commitments also affects state revenues and poses challenges in operating fiscal policy. Therefore, the study of the impact of trade liberalization on customs revenues, which is formed from the revenues for imports and exports, is really a matter of great concern to Vietnam.

Regarding the impact of trade liberalization on customs revenues, there have been many studies in Vietnam and around the world such as Hammar (2009), Khattry and Rao (2002), Glenday (2000), Gundogdu (2011), Chan and Dung (2003), Fukase and Martin (1999), Lanchovichina, Martin, and Wood (2000), and Tyers and Rees (2002). In general, these studies confirm the inevitable relationship between trade liberalization with the customs revenue of each country. There are also a number of studies that have attempted to quantify changes in the customs revenues of individual countries when undertaking trade liberalization. However, no studies have quantified and forecasted the impact of trade liberalization on customs revenues in Vietnam. There has also been no study showing the degree of the individual impact of each commitment in trade liberalization on customs revenues in Vietnam. Therefore, the author has written this article to consider the impact of trade liberalization on customs revenues in Vietnam. In particular, trade liberalization will be considered through aspects including tariff rate reduction, implementation of international commitments on customs regulations as well as exchange rates and import value. This study is really necessary because there are few empirical studies on the impact of trade liberalization on customs revenues in Vietnam. Other studies of the level of customs revenue change when trade liberalization occurs in Vietnam are mainly based on qualitative research methods. This research will fill this gap by applying empirical studies of some countries and quantifying some aspects of free trade in Vietnam.

\section{The Status of Customs Revenues and Trade Liberalization in Vietnam}

Globalization, international economic integration and trade liberalization have been a prominent trend of the contemporary world economy. In line with that trend, from 1986 up to now, Vietnam has carried out the renovation and accelerated international economic integration with the motto "diversify and multilateralism foreign relations." Regarding bilateral cooperation, Vietnam has established diplomatic relations with more than 170 countries around the world, expanding trade relations, exporting goods to more than 230 markets of countries and territories, signed over 90 bilateral trade agreements, nearly 60 agreements on investment encouragement and protection, 54 double taxation prevention agreements and many bilateral cultural cooperation agreements with countries and international organizations.

Regarding multilateral and regional cooperation, Vietnam has had a positive relationship with international financial and monetary organizations such as Asian Development Bank, International Monetary Fund, World Bank. The process of Vietnam's international economic integration has been promoted and taken to a higher level by joining regional and international economic and trade organizations, signing multilateral economic cooperation agreements. In July 1995, Vietnam joined the Association of Southeast Asian Nations (ASEAN) and officially joined the ASEAN Free Trade Area (AFTA) from January 1, 1996. This is considered a breakthrough in action in the process of international economic integration of Vietnam. Subsequently, in 1996 Vietnam joined the founding of the Asia-Europe Meeting (ASEM) and in 1998, Vietnam was admitted to the Asia-Pacific Economic Cooperation (APEC). In particular, Vietnam's international economic integration process has taken an important step when Vietnam officially became a member of the World Trade Organization (WTO) on January 11, 2007 after 11 years of negotiation to join this organization. Vietnam has agreed to comply with all WTO binding agreements and regulations from the time of accession and has fully implemented these commitments and obligations.

Customs is one of the areas with many commitments to change when Vietnam joins the WTO. These commitments cover 10 issues, including the implementation of customs valuation under the WTO; simplify customs procedures to facilitate trade; implementation of regulations on fees and charges in the WTO; implementation of WTO rules of origin; implementation of regulations on freedom of transit; strengthen anti-smuggling and trade frauds; improve management capacity and qualifications; modernize customs management; fulfill international security requirements against terrorism; enforce protection of intellectual property rights at the border under the TRIPS Agreement. During the reform process from 1998 up to now, Vietnam customs have been gradually implemented the above contents. Especially since the Customs Law (2001) and the Law amending and supplementing a number of articles of the Customs Law (2005), the above contents have been enhanced to be implemented in a clearer and more focused manner with WTO requirements.

Figure 1 illustrates that in past 15 years including 5 years before joining the WTO and 10 years after joining the WTO, 


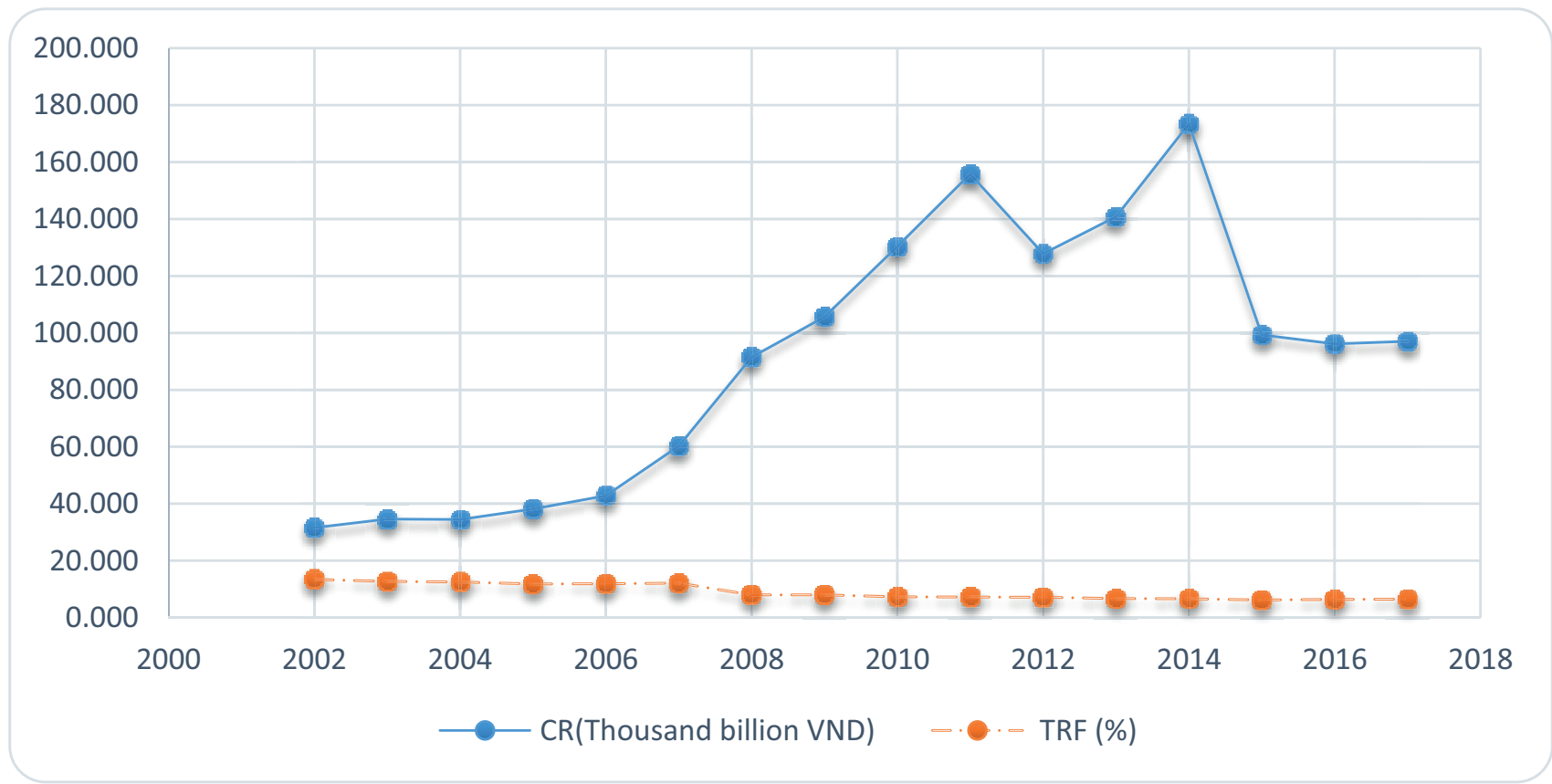

Figure 1: Vietnam customs revenue and average tariffs from 2002 to 2017

Source: CR - International publication data of Vietnam Ministry of Finance; TRF - http://data.worldbank.org/indicator/TM.TAX.MRCH.WM.AR.ZS?page=2

Vietnam's average tariff has continuously decreased from $13.4 \%$ in 2002 to $6.51 \%$ in 2017 . Especially, within a year after Vietnam officially joined the WTO, the average tariff dropped the most from $12.1 \%$ in 2007 to $8.1 \%$ in 2008 . This is the inevitable result of the process of international economic integration and implementation of tariff reduction in Vietnam. The period from 2007 to now is also the first 10-year period that Vietnam fully implemented its international commitments in the customs field in accordance with WTO regulations. Vietnam's customs revenue after the 2007 milestone increased sharply and continued to maintain that strong momentum until 2014. However, customs revenues began to decrease since 2015 although the tax rate has maintained the decrease rate. So is there any relation between the change in customs revenues and trade liberalization in Vietnam? How to predict this change in the future? Vietnam will undoubtedly continue to reduce taxes and strictly enforce customs commitments in the signed free trade agreements. Therefore, the study of the impact of trade liberalization on customs revenues in Vietnam, thereby proposing suggestions to ensure the state budget revenue has great significance for Vietnam.

\section{Literature Review}

According to the theory of tariffs, import taxes tend to increase prices in the domestic market, reduce imports and increase a country's budget revenue. Economist Laffer (2004) studied and proposed a curve model showing the relationship between tax rate and total tax revenue. Laffer (2004) has shown that tax increases in the United States will negatively impact social productivity and at a reasonable tax rate the total tax revenue will be maximized.

Hammar (2009) analyzed data for 2 months from late 2007 to early 2008 on the effects of trade liberalization on the Vietnamese economy. In this study, Hammar (2009) focused on analyzing the effects of eliminating non-tariff barriers in Vietnam on the national budget. Khattry and Rao (2002) demonstrated the natural relationship between government tax revenue and trade liberalization through qualitative analysis based on data from 80 developing countries during the period from 1970 to 1998. Glenday (2000) also discussed the relationship between trade liberalization and customs revenues, specifically choosing to analyze a specific case in Kenya. This study has confirmed that some of the main factors affecting Kenya's customs revenues. These factors includes import and export turnover, import and export duty policy, average import duty rate, ratio of input materials of agricultural products and the structure of imported products. From the regression analysis of the above factors, Glenday (2000) has confirmed that the state policy factors have a stronger effect than the impact of the tax rate factor. 
Pritchett and Sethi (1994) suggested that trade liberalization would help a country's economy grow efficiently, but the effect of tax cuts is not the same for every country. Similarly, Hye, Wizarat and Lau (2016) said that trade openness are positively related to economic growth in the long run and short run. Tu and Giang (2018) also showed that trade openness is a significant determinant of Vietnamese bilateral export value. Nguyen (2020) has proven that FDI and international trade are related to Vietnam's economic growth. Lower tariffs can cause customs revenues reduced. However, import volumes tend to expand when taxes are reduced. Tax reductions also reduce the opportunities and incentives for tax evasion, and increase the level of tax compliance, and thus customs revenues may increase. High tariffs provide incentives for importers to evade taxes or seek exemptions. How the tariff reduction effect in the economy will depend on the elasticity of demand for imported goods. If the elasticity is high enough and tax compliance is high, customs revenues will increase.

United Nations. Economic Commission for Africa, \& African Union. (2007) emphasizes that trade liberalization is often accompanied by the depreciation of nominal and real exchange rates. This increases the domestic value of imports, and positively impacts on customs revenues. However, the domestic costs of government spending programs will increase. Consumption will shift from imports to domestically produced goods, so customs revenues will decrease but revenues from domestic indirect taxes will increase. Therefore, the overall effect of exchange rate depreciation is also not clear for all countries when trade liberalization is carried out. In the long run trade liberalization can be driven by the growth performance of the national economy. As the economy grows, people's income levels will increase, creating opportunities for an increase in domestic income tax revenue. Ebrill, Stotsky and Gropp (1999) also agree with other studies when concluding that the impact of trade liberalization measures on customs revenues can be positive, negative and neutral depending on the specific points of each country.

Gundogdu (2011) pointed out the variables affecting the customs revenues of Islamic countries as WTO members by using annual data from 1995 to 2007 in a model that has format:

$$
\mathrm{CR}=\mathrm{f}(\mathrm{IMP}, \mathrm{TRF}, \text { IndTRF, CVA, IndCVA) }
$$

In particular, $\mathrm{CR}$ is the customs revenue; IMP is the volume of imports; TRF is the average tariff; CVA is a dummy variable that takes value 1 if the country at the time of observation implements the WTO Valuation Agreement and vice versa will be 0 ; IndTRF is a variable that shows the indirect effect of import tariffs through changes in the amount of imports, which is determined as the product of TRF and
IMP; IndCVA shows the indirect effect of implementing the WTO Valuation Agreement through changes in imports, this variable is determined to be the product of a country's CVA and IMP.

The research results of Gundogdu (2011) have proved that increasing import and export tax rates may increase customs revenues in countries with large-scale economy but not be true for countries with small-scale economy. The study also proves that the implementation of the WTO Valuation Agreement has no impact on changing the customs revenue so much because there is an interaction between the direct effects from the valuation of tax under the WTO value Agreement and its indirect effects. It can be seen that the success of Gundogdu (2011) is to identify the basic variables affecting a country's customs revenues, compare the level of influence of each factor on customs revenues, and identify the direct and indirect impact trends of each factor. In particular, the study suggested a way to quantify the implementation of the WTO Valuation Agreement into dummy variables to put in the research model.

However, Gundogdu (2011) only considers the impact of the WTO Valuation Agreement on customs revenues, but in fact each country still has to implement other commitments in the customs field that the author has mentioned above in this article. Therefore, in order to more accurately assess the impact of trade liberalization on customs revenues in Vietnam, the author proposes to replace the implementation of the WTO Valuation Agreement with the WTO accession variable. In addition, this study also has the limitation of omitting the exchange rate factor affecting customs revenues while most countries collect import and export taxes in local currencies, which will be heavily influenced by exchange rate fluctuations. Studying the relationship between trade liberalization and customs revenue, Epaphra (2014) proposed the following research model for the country of Tanzania.

$$
\text { IDR }=\mathrm{f}(\mathrm{CTR}, \mathrm{pcGDP}, \mathrm{RER}, \mathrm{IMPORT}, \mathrm{CTAX}, \mathrm{DTAX})
$$

In which, IDR is the import duties revenue; CTR is the collected tax rate; pcGDP is GDP per capita; RER is the real exchange rate; IMPORT is import turnover; CTAX is the domestic consumption tax; DTAX is the domestics income tax. In this study, Epaphra (2014) particularly emphasizes on exchange rate factor. This paper states that the impact of macroeconomic policies on import tax revenues is also recorded in real exchange rates. When the real exchange rate is high, the nominal import value is higher and thus the import tax increase. However, overvaluation of the real exchange rate, which is often taken by expanded financial policies, will adversely affect overall economic activities, and thus reduce overall tax revenue.

Similarly, Gaalya (2015) used fixed and random effects models to evaluate the determinants of tax collection 
efficiency based on data from 1994 to 2012. The study shows that exchange rates, trade openness and the ratio of industry to GDP positively influence the efficiency of tax collection. In contrast, the ratio of agriculture to GDP and foreign aid negatively affects the efficiency of tax collection. In particular, the trade openness variable is used as a proxy for trade liberalization.

In addition, there are many studies in Vietnam using the computable general equilibrium (CGE) to evaluate the impact of international economic integration on Vietnam's socioeconomy, including the state budget. Typically, the study of trade liberalization by Chan and Dung (2003), the study of implementation of AFTA commitments by Martin and Fukase (1999), or research on the United States's applying the most favored nation status to Vietnam by Fukase and Martin (2000), as well as research on the implementation of the Vietnam-US Bilateral Trade Agreement by Lanchovichina, Martin and Wood (2000), studies on WTO accession by Tyers and Rees (2002). However, no studies in Vietnam have quantified and forecasted the trend of the impact of trade liberalization on tax revenues in general and customs revenues in particular. It should be noted that empirical studies around the world have not resolved the debate on the impact of trade liberalization on tax revenue. The empirical research results also partly reflect the reality of a set of countries in an analysis period.

While trade liberalization can help foster integration in the world economy and promote efficient economic growth it is an inevitable outcome, the impact of trade liberalization on tax revenue is not clearly obvious to every country at every stage. Most studies on the impact of trade liberalization on tax revenue are based on a large sample of developing countries, a few focused on a number of emerging economies. Because researchers believe that developing countries' budget revenues depend greatly on customs revenues from imports and exports and the ability to find alternative sources of customs revenue is quite weak. Therefore, for the purpose of contributing to the debate on the impact of trade liberalization on tax revenue, on the basis of developing countries, the author conducted a study on trade liberalization and customs revenues in Vietnam. Thereby, the author also expects that the article will not only be meaningful for regulators in Vietnam, but may also add some ideas to the study of the relationship between trade liberalization and tax revenue in every country.

\section{Methodology and Data}

\subsection{Methodology}

This paper uses the vector error correction model (VECM) to estimate the short-term and long term relationship between data series, from which an equation (ECM) can be drawn to consider the impact of factors on customs revenues. Because time data are often unstable, estimating the relationship between these variables using the OLS method will lead to spurious regression, or in other words, the coefficients in the regression model do not accurately reflect the relationship of the variables in the model (Asteriou \& Hall, 2007). In order to overcome the limitations of the instability of time series variables in economic research, Sims (1980) and Greene (2000) proposed a VAR / VECM model. It is based on the assumption that the variation of time series variables are not only influenced by exogenous factors but are also influenced by endogenous factors (lag). Therefore, after taking the difference, the use of OLS method still shows the exact relationship between the time series variables with no stability.

According to Gundogdu (2011) and Epaphra (2014), the customs revenue of a country will mainly depend on variables such as import turnover, the average tariff, and implement of the WTO Valuation Agreement, the variable represents the indirect effect of the average tariff, the variable represents the indirect effect of the WTO Valuation Agreement and the exchange rate. However, in order to more accurately assess the effects of trade liberalization on customs revenues in Vietnam, in the previous section, the author proposed replacing the implementation of the WTO Valuation Agreement with the WTO accession variable. Therefore, the general research equation is as follows:

$$
\mathrm{CR}=\mathrm{f}(\mathrm{IMP}, \mathrm{TRF}, \text { IndTRF, WTO, IndWTO, EXR) }
$$

In which: CR is Vietnam's customs revenue quarterly from 2002 to 2017; IMP is Vietnam's import turnover quarterly from 2002 to 2017; TRF is Vietnam's average tariff rate quarterly from 2002 to 2017; IndTRF is the indirect impact variable of TRF in Vietnam which is the product of IMP and TRF; WTO is a dummy variable that takes value 1 if at the time of observation Vietnam has joined the WTO and vice versa will be 0 ; IndWTO is a variation of the indirect effect of WTO accession in Vietnam, which is the product of IMP and WTO; EXR is the average quarterly exchange rate variable from 2002 to 2017 in Vietnam. However, due to data on customs revenues, imports, and foreign exchange rates has a great variation over time, so when using it in the model, the author will use the logarithm nepe function for these 3 variables to limit the degree of variability of the data series. At the same time, the logarithm nepe function allows the study to show more clearly the elasticity of customs revenues according to the independent variables in the model.

\subsection{Data Description}

The customs revenues collected by the customs authorities from goods imported and exported enterprises, 
include: export tax, import tax; special consumption tax, value-added tax and an environmental protection tax for imported goods, etc. Data on Vietnam's customs revenues during 2005 - 2017 is collected based on quarterly reports on the Ministry of Finance's website in the international data quarterly section on customs revenues; from 2002 to 2004, collected on the Government's Web Portal reporting the socio-economic situation quarterly.

Import turnover is the balance in currency of a country for import goods and services in a fixed time period usually lasting months, quarters or years. Import turnover by quarter in Vietnam is based on the data collected on the official website of the Government's Web Portal, in the section on the situation of socio-economic development quarterly from 2002 to 2017.

Average tariff rate is the average import tax rate that takes into account the weight of the corresponding import value of goods. The World Bank has announced the average tariff of several countries on its official website including Vietnam from 2002 to 2017.

The WTO accession variable is a dummy variable. Specifically, the WTO accession variable will receive a value of 1 at the time of observation that Vietnam has joined the WTO and vice versa will receive a value of 0 . Vietnam officially became the 150th member of the WTO on 11 January 2007. Therefore, the WTO variable will receive a value of 0 in the observations from 2002 to the end of 2006 and will receive a value of 1 in the observations from 2007 to 2017.

The quarterly average exchange rate variable is calculated based on historical data on the monthly USD / VND exchange rate officially published on the International Financial Portal investing.com.

\section{Empirical Results and Discussion}

\subsection{Stationary and Unit Root Test}

The test results show that all data series are non-stationary at the original data series, but they all are stationary after taking the first level of difference, or in other words, these data series are I (1).

\subsection{Optimal Lag}

The initial goal was to determine if there was a longterm equilibrium relationship between customs revenues and the variables representing the degree of trade liberalization in Vietnam. First, the author needs to determine the optimal lag in the Vector Auto regression (VAR) model. The author selected based on the majority criteria of AIC (Akaike's information criterion), FPE (Final prediction error), LR (likelihood-ratio test) and HQ (Hannan-Quinn information criterion). This process resulted in the selection of a lag length of 4 for the data (see Table 1).

\subsection{Cointegration Analysis}

The results of the co-integration test by Johansen method indicate that the hypothesis that there are at least three cointegrating relationships is accepted. That means there is cointegration between the variables in the model at a lag of 4 (see Table 2).

Thus there is preliminary evidence to conclude that there exists a long term equilibrium relationship between the variables in the model. With this result, the paper will conduct estimation according to VECM method. The long term equilibrium relationship between variables in the model is described by the following equation:

$$
\begin{aligned}
\operatorname{LnCR}= & -10.33971 \operatorname{LnIMP}+10.01882 \operatorname{LnEXR} \\
& -4.964006 T R F-0.0289211 \operatorname{IndTRF} \\
& -8.729186 W T O+0.055718 I n d W T O
\end{aligned}
$$

The above equation shows that Regression coefficients of all variables are statistically significant. The tariff reduction and customs management reforms as committed in the WTO have both direct and indirect impacts on import and export tax revenues in Vietnam in the long term. Specifically, when

Table 1: Determine the lag length of the model based on the VAR model

\begin{tabular}{|c|c|c|c|c|c|c|}
\hline Lag & LogL & LR & FPE & AIC & SC & HQ \\
\hline 0 & -184.5581 & NA & $1.56 \mathrm{e}-06$ & 6.493495 & $6.739983^{*}$ & 6.589714 \\
\hline 1 & -134.7548 & 86.10059 & $1.53 \mathrm{e}-06$ & 6.466265 & 8.438165 & 7.236015 \\
\hline 2 & -77.82070 & 84.91871 & $1.26 \mathrm{e}-06$ & 6.197312 & 9.894624 & 7.640593 \\
\hline 3 & 22.95548 & 126.3972 & $2.61 \mathrm{e}-07$ & 4.442187 & 9.864912 & 6.558999 \\
\hline 4 & 195.2525 & $175.2173^{*}$ & $5.88 \mathrm{e}-09^{*}$ & $0.262627^{*}$ & 7.410765 & $3.052971^{*}$ \\
\hline * indicates lag order selected by the criterion & & & \\
\hline
\end{tabular}


Table 2: Cointegration test results of variables in the model

\begin{tabular}{|c|c|c|c|c|c|c|}
\hline Lag & LogL & LR & FPE & AIC & SC & HQ \\
\hline 0 & -184.5581 & NA & $1.56 \mathrm{e}-06$ & 6.493495 & $6.739983^{*}$ & 6.589714 \\
\hline 1 & -134.7548 & 86.10059 & $1.53 \mathrm{e}-06$ & 6.466265 & 8.438165 & 7.236015 \\
\hline 2 & -77.82070 & 84.91871 & $1.26 \mathrm{e}-06$ & 6.197312 & 9.894624 & 7.640593 \\
\hline 3 & 22.95548 & 126.3972 & $2.61 \mathrm{e}-07$ & 4.442187 & 9.864912 & 6.558999 \\
\hline 4 & 195.2525 & $175.2173^{*}$ & $5.88 \mathrm{e}-09^{*}$ & $0.262627^{*}$ & 7.410765 & $3.052971^{*}$ \\
\hline * indicates lag order selected by the criterion & & & \\
\hline
\end{tabular}

the average tariff decreases by $1 \%$, Vietnam's customs revenues increase by about $5 \%$. This result also shows that the reform of customs management will have the effect of reducing customs revenues and is only partially offset by the indirect effects in the long term. These indirect effects are an inevitable consequence of increasing import turnover, reducing the incentive for tax evasion and fraud. Besides, the above results also show that in the long term, the exchange rate also has a significant positive effect on customs revenues. Specifically, if the USD / VND exchange rate increased by $1 \%$, the customs revenue in Vietnam increased by about $10 \%$, a pretty high number. This implies that proper exchange rate policy is also a good solution to ensure customs revenues in Vietnam.

\subsection{Correlation Analysis and Estimation of VECM}

The results of the Pearson correlation analysis show that all variables have an impact on customs revenues in Vietnam. However, to consider the impact of factors on customs revenues, the author conducted the regression analysis in the following steps.

Table 3 shows that in the short term trade liberalization associated with tariff reductions and tax revenue reforms tends to have different effects on changes in customs revenues in Vietnam. Specifically, the coefficients C (1), C (2), C (3) and $\mathrm{C}$ (4) show the dependence of the customs revenues on itself in the previous quarters. Most of these coefficients are negative. This shows that the customs revenue has a seasonal adjustment. If the previous quarters decreased, the next quarter tended to increase and vice versa. The coefficients $\mathrm{C}$ (8) and C (9) show the impact of import turnover on customs revenue in Vietnam. These coefficients are also negative. That means that in the short term, increasing import turnover has no effect on increasing customs revenues. This can be explained that when implementing trade liberalization in Vietnam, the import tax rate dropped sharply, many kinds of goods were exempted from tax, so even though the import turnover increased, the total import tax did not necessarily increase. The coefficients C (15) and C (17), representing the direct effect of tariff reductions on customs revenues in Vietnam, are also negative. This suggests that in the short term, tariff reductions have an immediate positive impact on Vietnam's customs revenues. It is understandable that Vietnam had high taxation before expanding international integration, so there may be an excess taxing situation in the economy, when reducing the tax rate, there is an effect of increasing customs revenue immediately.

Meanwhile, the coefficients C (18) C (19) and C (20) show the direct impact of the implementation of international commitments on tax collection in the WTO to customs revenues in Vietnam. These coefficients are positive, so in the short term, this reform will also have positive impacts on export tax revenues. These reforms can help businesses to be more proactive in international business so they can easily access the world market and expand their business. Positive coefficients C (23), C (24), C (25) show that the indirect effect of tariff reduction is to reduce customs revenues in the short term. This is because in the short term, the increase in import turnover is not enough to offset the decrease of tariffs. Similarly, the coefficients C (28) and C (29) representing the indirect effects of tax collection reform are also negative, suggesting a reduction in customs revenues. The tax collecting reform gives taxpayers the right to declare themselves, responsible themselves for the taxable valuation information while the state agencies do not have enough data sources to verify the integrity of declaration information of enterprise. Therefore, there are many cases of deliberate commercial frauds to avoid tax in the short term. Besides, the results of this short-term estimation model show that no regression coefficients of EXR are statistically significant. This shows that in the short term, the exchange rate in Vietnam has hardly changed because Vietnam maintains the controlled - floating exchange rate policy, so there is little change in the short term. Therefore, exchange rates do not have any impact on customs revenues in the short term. 
Table 3: Summary of regression coefficients with statistical significance

\begin{tabular}{|c|c|c|c|c|c|}
\hline & Correlation coefficient & Standard errors & Statistics t & Probability & Significance \\
\hline $\mathrm{C}(1)$ & 0.056990 & 0.023809 & 2.393642 & 0.0234 & ${ }^{* *}$ \\
\hline $\mathrm{C}(2)$ & -0.356755 & 0.175352 & -2.034515 & 0.0511 & ${ }^{*}$ \\
\hline $\mathrm{C}(3)$ & -0.456430 & 0.171798 & -2.656777 & 0.0127 & ${ }^{* *}$ \\
\hline $\mathrm{C}(4)$ & -0.407352 & 0.160868 & -2.532215 & 0.0170 & ${ }^{* *}$ \\
\hline $\mathrm{C}(8)$ & -2.630233 & 1.097832 & -2.395844 & 0.0233 & ${ }^{* *}$ \\
\hline $\mathrm{C}(9)$ & -2.570204 & 1.109157 & -2.317259 & 0.0278 & ${ }^{* *}$ \\
\hline $\mathrm{C}(15)$ & -0.451846 & 0.236207 & -1.912925 & 0.0657 & ${ }^{*}$ \\
\hline $\mathrm{C}(17)$ & -0.810805 & 0.286026 & -2.834724 & 0.0083 & ${ }^{* * *}$ \\
\hline $\mathrm{C}(18)$ & 1.847432 & 0.887424 & 2.081791 & 0.0463 & ${ }^{* *}$ \\
\hline $\mathrm{C}(19)$ & 2.720456 & 1.047950 & 2.595977 & 0.0147 & ${ }^{* *}$ \\
\hline $\mathrm{C}(20)$ & 2.679434 & 1.057350 & 2.534103 & 0.0169 & ${ }^{* *}$ \\
\hline $\mathrm{C}(23)$ & 0.022518 & 0.012681 & 1.775740 & 0.0863 & ${ }^{*}$ \\
\hline $\mathrm{C}(24)$ & 0.033534 & 0.013337 & 2.514449 & 0.0177 & ${ }^{* *}$ \\
\hline $\mathrm{C}(25)$ & 0.036088 & 0.013641 & 2.645565 & 0.0130 & ${ }^{* *}$ \\
\hline $\mathrm{C}(27)$ & -0.139915 & 0.058581 & -2.388424 & 0.0237 & ${ }^{* *}$ \\
\hline $\mathrm{C}(28)$ & -0.153904 & 0.057489 & -2.677109 & 0.0121 & ${ }^{* *}$ \\
\hline $\mathrm{C}(29)$ & -0.133717 & 0.066082 & -2.023481 & 0.0523 & ${ }^{* *}$ \\
\hline $\mathrm{C}(30)$ & -0.199670 & 0.094717 & -2.108056 & 0.0438 & ${ }^{* *}$ \\
\hline
\end{tabular}

The symbol ***, ${ }^{* *},{ }^{*}$ corresponds to the statistical significance level of $1 \%, 5 \%$ and $10 \%$ respectively.

Table 4: Result of analysis of impulse response function

\begin{tabular}{|c|c|c|c|c|c|c|c|}
\hline Period & LNCR & LNIMP & LNEXR & TRF & INDTRF & WTO & INDWTO \\
\hline 1 & 0.186529 & 0.000000 & 0.000000 & 0.000000 & 0.000000 & 0.000000 & 0.000000 \\
\hline 2 & 0.154844 & 0.031411 & 0.008786 & -0.004090 & 0.006710 & 0.023355 & -0.036942 \\
\hline 3 & 0.124225 & 0.064657 & 0.018040 & -0.015065 & -0.005272 & 0.046064 & -0.051827 \\
\hline 4 & 0.109652 & -0.009159 & 0.012122 & 0.016256 & -0.006288 & 0.020286 & -0.040106 \\
\hline 5 & 0.159007 & 0.021928 & 0.017221 & 0.020356 & 0.016867 & 0.058888 & -0.033834 \\
\hline 6 & 0.131947 & 0.015093 & 0.001830 & 0.026788 & -0.033773 & 0.039006 & -0.007899 \\
\hline 7 & 0.134332 & 0.047420 & -0.004810 & 0.042899 & -0.059675 & 0.070742 & -0.004284 \\
\hline 8 & 0.098597 & -0.004466 & 0.009060 & 0.015597 & -0.036299 & 0.005124 & -0.020723 \\
\hline 9 & 0.137757 & 0.017124 & 0.012557 & 0.037138 & -0.031981 & 0.004105 & -0.009863 \\
\hline 10 & 0.121234 & 0.012277 & -0.020777 & 0.035340 & -0.031936 & -0.017984 & -0.030899 \\
\hline
\end{tabular}

\subsection{Model Verification}

The test results of the residual show that the residuals of the VECM regression model are stationary with a high level of statistical significance $(p-$ value $=0,000)$. From the results of the stationary test, the autocorrelation and the variance change of the residual in the regression model show that the residual from the ECM model is a white noise. Then, the model estimation result is a BLUE (Best Linear
Unbiased Estimator) estimate. Therefore, ECM regression results are reliable.

\subsection{Analysis of Impulse Response Function}

Table 4 shows the results of impulse response function that shows more clearly the trends of the impact of variables in the model. This result is similar to the estimation results of the model in the short-term and long-term. 
Table 5: Result of Variance Decomposition of customs revenue

\begin{tabular}{|c|c|c|c|c|c|c|c|c|}
\hline Period & S.E. & LNCR & LNIMP & LNEXR & TRF & INDTRF & WTO & INDWTO \\
\hline 1 & 0.186529 & 100.0000 & 0.000000 & 0.000000 & 0.000000 & 0.000000 & 0.000000 & 0.000000 \\
\hline 2 & 0.248607 & 95.08817 & 1.596385 & 0.124899 & 0.027071 & 0.072858 & 0.882517 & 2.208098 \\
\hline 3 & 0.294629 & 85.47988 & 5.952498 & 0.463851 & 0.280711 & 0.083888 & 3.072758 & 4.666415 \\
\hline 4 & 0.318409 & 85.04801 & 5.179325 & 0.542093 & 0.501000 & 0.110821 & 3.036816 & 5.581934 \\
\hline 5 & 0.364357 & 83.99487 & 4.317584 & 0.637384 & 0.694748 & 0.298922 & 4.931350 & 5.125144 \\
\hline 6 & 0.392224 & 83.80063 & 3.873941 & 0.552209 & 1.065977 & 0.999388 & 5.244539 & 4.463315 \\
\hline 7 & 0.429628 & 79.62029 & 4.446994 & 0.472776 & 1.885462 & 2.762215 & 7.082350 & 3.729913 \\
\hline 8 & 0.443194 & 79.77015 & 4.189087 & 0.486067 & 1.895659 & 3.266509 & 6.668802 & 3.723722 \\
\hline 9 & 0.467295 & 80.44436 & 3.902404 & 0.509428 & 2.336769 & 3.406620 & 6.006358 & 3.394065 \\
\hline 10 & 0.487023 & 80.25563 & 3.656198 & 0.650989 & 2.677836 & 3.566205 & 5.665959 & 3.527188 \\
\hline
\end{tabular}

\subsection{Variance Decomposition of Customs Revenue}

Table 5 shows the results of the variance decomposition that in the first stage the change in customs revenues coming from itself accounting for $100 \%$ regardless of other variables in the model. In the medium term, the change in customs revenues comes from itself accounting for $83.99 \%$ and in the long term $80.25 \%$. In particular, the role of import turnover tends to increase over time and accounts for $3.6 \%$ of the causes of changes in import and export tax revenues in the long term. The role of the exchange rate also increases over time but is quite low at only $0.65 \%$ of the causes of long-term revenue changes. The total impact of the average tariff and the reform of tax collection under international commitments to customs revenues is $6.2 \%$ and $9.1 \%$, respectively. This shows that trade liberalization has not too strong impact on changes in Vietnam's customs revenues. The total impact of trade liberalization, including tariff reductions, elimination of trade barriers, administrative procedure reforms, is only about $15 \%$.

\section{Conclusion and Policy implications}

Using the VECM model for data samples from the first quarter of 2002 to the fourth quarter of 2017, the article showed that trade liberalization will have a direct and indirect effect on changes in customs revenues in Vietnam.

In the short term, tariff reduction and implementation of international commitments on customs management reforms have a direct positive impact on Vietnam's customs revenues. This is explained by the fact that Vietnam has maintained a relatively high import tax rate for a long time when Vietnam has not had extensive international integration in order to protect domestic production. That makes businesses have many motives for tax evasion and fraud. When reducing tariffs, the amount of tax payable per unit of product will be reduced, creating incentives for more import and minimizing tax evasion. Therefore, immediately the direct effect of tariff reduction is to increase imports, thereby increasing customs revenues in Vietnam. This is also entirely consistent with Laffer curve theory. However, in the short-term research's results also note that the indirect effect of tax reduction reduces customs revenues in Vietnam? This can be explained by the lag effect of income so the increase in demand leading to an increase in import turnover is not enough to offset the decrease of the tax rate. However, over time when the income effect is strong enough, according to the theory of supply and demand, the volume of imported goods will gradually increase, leading to an increase in customs revenues in the long run as the model's long-term estimates.

In addition, the implementation of international commitments in customs management has also removed a lot of non-tariff barriers and created fairness for all businesses involved in import and export activities. For example, when these commitments have not been implemented, the enterprise will have to determine the taxable value according to the minimum taxable price list - a control tool that can increase the tax payable on imported goods. Enterprises also face many difficulties in determining the origin of goods to enjoy preferential tax rates, nor are there any unified rules in applying HS codes for goods to select the appropriate tax line. Those things really cause a lot of difficulties for businesses to determine business costs and profit levels. Therefore, when implementing international commitments in customs management, enterprises are entitled to determine the dutiable value, origin of goods and HS codes of goods according to their declarations. If the Customs Office suspects that the enterprise cheats in the declaration, the customs office may only invite the enterprise to explain or transfer the inspection after the customs clearance. This approach helps businesses reduce the time for import and export clearance, anticipate the cost of import and export, and be much more active in participating in the world market. 
Therefore, the scale of Vietnam's import and export has increased significantly, creating a positive effect on customs revenues. However, the short-term research results also note that the indirect effects of average tariffs and the implementation of international commitments on customs management all reduce customs revenues in Vietnam. This can be explained for two main reasons as follows. For the tariff reduction, due to the lag of the income effect, the increase in demand leading to an increase in import turnover is not enough to offset the reduction of the tax rate. The implementation of international commitments in customs management creates too many advantages in the international business of enterprises.

But in the short term, the lack of management experience, weakness and loopholes of legal documents and regulations that create conditions for fraud and ovations cause losses in customs revenues.

Besides, the research results also show that the exchange rate factor in the short term has almost no impact on customs revenues because Vietnam is nearly stable exchange rate in the short term. However, in the long run, when the exchange rate increases, customs revenues increase sharply. This shows that if Vietnam maintains a weak VND policy, high USD / VND exchange rate, this increases the domestic value of imports, and positively impacts customs revenues. It will benefit not only Vietnam's exports but also customs revenue. And the fact shows that China has been very successful in international trade with weak CNY policy.

In particular, this study shows that tariffs are no longer the main cause of changes in customs revenues in Vietnam. Specifically, the decomposition of customs revenues shows that the total indirect and direct impact of the average tariff only accounts for $6 \%$ of the causes of the change in import and export tax revenues. This result shows that the tariff reductions will not cause major changes in customs revenues and have a slight impact on the customs revenue in the short and long term. This implies that authorities should not be too concerned about tariff reductions in Vietnam, as customs revenues are no longer sensitive to tariff increases. This is also evidenced by the fact that right after joining the WTO in 2007, Vietnam has greatly reduced tariff lines but it did not cause a significant decrease in customs revenues. Therefore, joining the new generation FTAs of Vietnam in the coming time with a stronger level of tariff reduction should not be considered as a great pressure on customs revenues. Vietnam's customs revenues will largely depend on the effectiveness of implementation of international commitments on customs management. Therefore, to ensure customs revenues, the government need to have some policy to improve the efficiency of customs management in Vietnam.

\section{References}

Asteriou, D., \& Hall, S. G. (2007). Applied Econometrics: a modern approach (revised edition). Hampshire, UK: Palgrave Macmillan.

Chan, N., \& Dung, T. K. (2003). Using Structuralist CGE Model to Evaluate Impacts of Trade Liberalization in Vietnam. In Final Dissemination Workshop of Research Project "The effects of External Liberalization on Vietnam Economic Performance and Income Distribution" funded by the Ford Foundation (Vol. 21).

Ebrill, L. P., Stotsky, J. G., \& Gropp, R. (1999). Revenue implications of trade liberalization (Vol. 180). Washington, DC: International Monetary Fund.

Epaphra, M. (2014). The Revenue Implications of Trade Liberalization in Tanzania. Journal of World Economic Research, 3(3), 25-36.

Fukase, E., \& Martin, W. (2000). The effects of the United States granting MFN status to Vietnam. Weltwirtschaftliches Archive, 136(3), 539-559.

Gaalya, M. S. (2015). Trade liberalization and tax revenue performance in Uganda. Modern Economy, 6(2), 228-244. doi: 10.4236/me.2015.62021.

Glenday, G. (2002). Trade liberalization and customs revenues: Does trade liberalization lead to lower customs revenues? The case of Kenya. Journal of African Development, 5(2), 86-118.

Greene, W. H. (2000). Econometric analysis (4th ed.). Upper Saddle River, NJ: Prentice Hall.

Gundogdu, A. S. (2011). Determinants of OIC Countries' Customs Revenue vis-a-vis Implementation of WTO Customs Valuation Agreement. Journal of Economic Cooperation \& Development, 32(3), 39-64.

Hammar, T. (2009). Trade facilitation in Viet Nam, Recent progress and impact. Master's thesis. Department of Economics, School of Economics, Lund University.

Hye, Q. M., Wizarat, S., \& Lau, W. Y. (2016). The impact of trade openness on economic growth in China: An empirical analysis. Journal of Asian Finance, Economics and Business, 3(3), 27-37. https://doi.org/10.13106/jafeb.2016. vol3.no3.27.

Khattry, B., \& Rao, J. M. (2002). Fiscal faux pas?: an analysis of the revenue implications of trade liberalization. World Development, 30(8), 1431-1444.

Laffer, A. B. (2004). The Laffer curve: Past, present, and future. Backgrounder, 1765, 1-16.

Lanchovichina, E., Martin, W., \& Wood, C. (2000). Effects of the Vietnam-US bilateral trade agreement. Mimeo, World Bank.

Martin, W., \& Fukase, E. (1999). A Quantitative evaluation of Vietnam's accession to the ASEAN Free Trade Area. Washington, DC: The World Bank. 
Nguyen, H. H. (2020). Impact of Foreign Direct Investment and International Trade on Economic Growth: Empirical Study in Vietnam. Journal of Asian Finance, Economics, and Business, 7(3), 323-331. https://doi.org/10.13106/jafeb.2020. vol7.no3.323

Pritchett, L., \& Sethi, G. (1994). Tariff rates, tariff revenue, and tariff reform: some new facts. The World Bank Economic Review, 8(1), 1-16.

Sims, C. A. (1980). Macroeconomics and Reality. Econometrica, $48,1-48$.

Tu, M. T. C., \& Giang, H. T. T. (2018). Estimating the Impact of Trade Cost on Export: A Case Study Vietnam. Journal of Asian
Finance, Economics and Business, 5(3), 43-50. http://doi. org/10.13106/jafeb.2018.vol5.no3.43

Tyers, R., \& Rees, L. (2002). Trade Reform and Macroeconomic Policy in Vietnam. Working Papers in Economics and Econometrics No. 419. Presented at the Fifth Annual Conference on Global Economic Analysis, Taipei, June.

United Nations. Economic Commission for Africa, \& African Union. (2007). Economic Report on Africa 2007: Accelerating Africa's Development through Diversification. New York, NY: United Nations Publications. 
